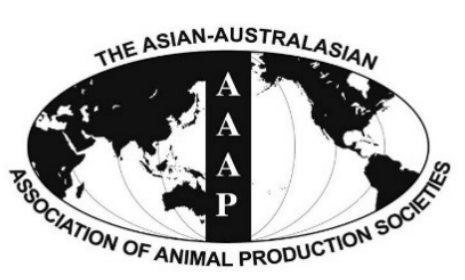

Open Access

Asian Australas. J. Anim. Sci.

Vol. 29, No. 9 : 1273-1279 September 2016

http://dx.doi.org/10.5713/ajas.15.0798

www.ajas.info

pISSN 1011-2367elSSN 1976-5517

\title{
Optimal Cultivation Time for Yeast and Lactic Acid Bacteria in Fermented Milk and Effects of Fermented Soybean Meal on Rumen Degradability Using Nylon Bag Technique
}

\author{
S. Polyorach*, O. Poungchompu', M. Wanapat ${ }^{2}$, S. Kang ${ }^{3}$, and A. Cherdthong ${ }^{2}$ \\ Department of Animal Production Technology and Fisheries, Faculty of Agricultural Technology, \\ King Mongkut's Institute of Technology Ladkrabang, Bangkok 10520, Thailand
}

\begin{abstract}
The objectives of this study were to determine an optimal cultivation time for populations of yeast and lactic acid bacteria (LAB) co-cultured in fermented milk and effects of soybean meal fermented milk (SBMFM) supplementation on rumen degradability in beef cattle using nylon bag technique. The study on an optimal cultivation time for yeast and LAB growth in fermented milk was determined at $0,4,8,24,48,72$, and $96 \mathrm{~h}$ post-cultivation. After fermenting for 4 days, an optimal cultivation time of yeast and LAB in fermented milk was selected and used for making the SBMFM product to study nylon bag technique. Two ruminal fistulated beef cattle $(410 \pm 10 \mathrm{~kg})$ were used to study on the effect of SBMFM supplementation $(0 \%, 3 \%$, and $5 \%$ of total concentrate substrate) on rumen degradability using in situ method at incubation times of $0,2,4,6,12,24,48$, and $72 \mathrm{~h}$ according to a Completely randomized design. The results revealed that the highest yeast and LAB population culture in fermented milk was found at $72 \mathrm{~h}$-post cultivation. From in situ study, the soluble fractions at time zero (a), potential degradability (a+b) and effective degradability of dry matter (EDDM) linearly $(p<0.01)$ increased with the increasing supplemental levels and the highest was in the 5\% SBMFM supplemented group. However, there was no effect of SBMFM supplement on insoluble degradability fractions (b) and rate of degradation (c). In conclusion, the optimal fermented time for fermented milk with yeast and LAB was at 72 h-post cultivation and supplementation of SBMFM at 5\% of total concentrate substrate could improve rumen degradability of beef cattle. However, further research on effect of SBMFM on rumen ecology and production performance in meat and milk should be conducted using in vivo both digestion and feeding trials. (Key Words: Soybean Meal Fermented Milk, Rumen Degradability, Yeast, Lactic Acid Bacteria, Nylon Bag Technique)
\end{abstract}

\section{INTRODUCTION}

In livestock production, feed resources are very important in tropical regions, especially during the dry season. The security of feed is becoming critical in terms of

\footnotetext{
* Corresponding Author: S. Polyorach. Tel: +66-2-326-4313, Fax: +66-2-326-4313, E-mail: neenart324@hotmail.com

${ }^{1}$ Department of Animal Science, Faculty of Natural Resources, Rajamangala University of Technology-Isan, Phang Khon, Sakon Nakhon 47160, Thailand.

${ }^{2}$ Tropical Feed Resources Research and Development Center (TROFREC), Faculty of Agriculture, Khon Kaen University, Muang, Khon Kaen 40002, Thailand.

3 Agricultural Unit, Department of Education, National Institute of Education, Phnom Penh 12410, Cambodia.

Submitted Sept. 24, 2015; Revised Nov. 19, 2015; Accepted Dec. 18, 2015
}

quantity and quality, particularly protein sources which effect productivity performance. Researchers are attempting to find alternative protein sources which may help to increase livestock productivity (Wanapat and Rowlinson, 2007). Soya bean (Glycine max) is an economic crop used for both human and animal feeding. Soybean meal is the by-product of the extraction of soybean oil. It is the most important protein source used to feed farm animals. Soya bean meal is usually standardized commercially to contain $44 \%$ or $48 \%$ crude protein (CP) (Pond et al., 2005). Many researchers are seeking strategies to improve nutritive value of by-products and local feeds such as cassava chip, rice straw, rice bran, soybean meal, etc. Incorporation of microbial additives such as a culture of Saccharomyces cerevisiae and lactic acid bacteria (LAB) to the diet has become a common practice in ruminant nutrition 
(Polyorach et al., 2012). It has been widely used for protein production. Eukaryotic and prokaryotic microorganisms can be considered a suitable host for the production due to the rapid growth of microorganisms and a broader range of materials which may be considered as suitable substrates depending on the microorganism chosen.

The process of protein enrichment of animal feed using microorganisms to improve the nutritional value of animal has been evaluated. Oboh and Akindahinsi (2003) reported that Saccharomyces cerevisae could also be used for enriching cassava products. Boonnop et al. (2009) demonstrated that supplementation of cassava chips with Bakers' yeast (S. cerevisae) could increase CP from $2.0 \%$ to 32.4\%. Moreover, Polyorach et al. (2012) reported that yeast fermented cassava chip protein (YEFECAP) could be prepared to increase CP level up to $47 \%$. The effect of YEFECAP as protein source on rumen ecology and ruminant production performance has been evaluated by previous studies of Polyorach et al. (2014a) Boonnop et al. (2010) and Wanapat et al. (2011). The method of upgrading the protein content of soybean meal has been developed. Moreover, LAB are the principal organism involved in the production of fermented feed. It is well known that LAB in fermented feed can exert health benefits for animals (Canibe and Jensen, 2012; Sugiharto et al., 2015).

Fermented milk products are regarded as predominantly lactic fermentations, the frequent occurrence of yeasts and LAB has led to the suggestion that interactions may occur which could influence product characteristics and quality. However, the mechanisms of possible interaction between yeasts and the lactic flora have not been widely studied. Such interaction may produce stimulation or inhibition of growth of one, or both, of the co-cultured strains (Narvhus and Gadaga, 2003). Recently, Polyorach et al. (2014b) has reported that soybean meal nutritive value has been improved with fermented milk using yeast and LAB. Fermented soybean meal with fermented milk product could increase CP from $46.8 \%$ to $70.6 \%$ while fiber content was decreased compared with unfermented group. Therefore, soybean meal fermented milk (SBMFM) is a potential protein source for ruminant.

However, the use of SBMFM as a protein source for ruminants is still affected by lack of data. Therefore, the objectives of this study were to determine an optimal cultivation time of populations of yeast and LAB co-culture in fermented milk and the effects of SBMFM supplementation on rumen degradability in beef cattle using nylon bag technique.

\section{MATERIALS AND METHODS}

\section{Fermented milk preparation}

Yeast and LAB cultivation was done according to the method of Polyorach et al. (2014b) and in brief was as follows: i) Activated yeast: weighed $20 \mathrm{~g}$ of Baker's yeast into a flask and mixed with $20 \mathrm{~g}$ of sugar plus $100 \mathrm{~mL}$ of distill water. The mixture was then incubated at room temperature for $1 \mathrm{~h}(\mathrm{~A})$. ii) Activated LAB: mixed commercial yoghurt $50 \mathrm{~g}$, molasses $25 \mathrm{~g}$ and adding distilled water $25 \mathrm{~mL}$, and then incubated at room temperature for 2 $\mathrm{h}$ (B). iii) Mixed (A) and (B) with $500 \mathrm{~g}$ of raw milk. The fermented milk was sampled at $0,4,8,24,48,72$, and $96 \mathrm{~h}$ post-cultivation for determination of yeast and LAB populations using direct counting.

\section{Soybean meal fermented milk production}

The SBMFM was prepared by mixing fermented milk (72 $\mathrm{h}$ post-cultivation) with soybean meal at proportion of 1 $\mathrm{mL}$ : $1 \mathrm{~kg}$ (fermented milk product: soybean meal) and fermented for 3 days. The product then was sundried for 2 days and stored in plastic bag.

\section{In situ trial}

Animals and dietary treatment: Two rumen fistulated crossbred beef cattle $(410 \pm 10 \mathrm{~kg})$ were used to determine the effect of SBMFM supplementation on rumen degradation using nylon bag technique according to completely randomized design. The dietary treatments were different levels of SBMFM supplement at $0 \%, 3 \%$, and $5 \%$ of total concentrate substrate. All animals were housed in individual pens and fed rice straw ad libitum with concentrate $(14 \% \mathrm{CP})$ supplemented at $0.5 \%$ body weight. Animals had free access to fresh water and trace mineralized salt. The diets were offered in two equal meals at 7.00 and 16.30 hour for 10 days before the initiation of the in situ experiment.

Nylon bag techniques: Samples were collected, ovendried at $60^{\circ} \mathrm{C}$ for $72 \mathrm{~h}$, ground to pass through a $1 \mathrm{~mm}$ screen and prepared for in sacco analysis. Ruminal degradation of the feed fractions was determined by the nylon bag technique (Orskov and McDonald, 1979). Bags $7 \times 4 \mathrm{~cm}$ in size with a pore size of $38 \mu \mathrm{m}$, were used. Three grams of each sample treatments were placed into the bags and tied tightly with nylon thread. Bags were tied to a weighed chain and placed in the ventral rumen sac of steers at approximate $2 \mathrm{~h}$ after the morning feeding. All feeds were incubated simultaneously in both steers using duplicates bags per feed at each time point and a blank bag containing no sample for each removal time. Bags of each feed were removed after $0,2,4,6,12,24,48$, and $72 \mathrm{~h}$ of incubation. Immediately after removal from the rumen, the bags were washed with cold tap water until rinsed clear water and oven-dried at $60^{\circ} \mathrm{C}$ for $72 \mathrm{~h}$. The bags were weighed and residues were removed and then analyzed for dry matter (DM). All bags of feed samples were collected for their corresponding blank. The $0 \mathrm{~h}$ incubation samples 
were washed and dried in similar condition. During each time, ruminal $\mathrm{pH}$ and temperature were measured immediately in both cattle using a portable $\mathrm{pH}$ and temperature meter from.

\section{Chemical composition analysis}

The samples were analyzed for DM, organic matter (OM), ether extract (EE), and $\mathrm{CP}$ according to AOAC (1990). Neutral detergent fiber (NDF) and acid detergent fiber (ADF) were determined using the method of Goering and Van Soest (1970).

\section{Rumen degradability}

The ruminal disappearance characteristics of DM was fitted to the exponential following the procedure described by Orskov and McDonald (1979) and using the NEWAY program (Chen, 1996): $\mathrm{p}=\mathrm{a}+\mathrm{b}\left(1-\mathrm{e}^{-\mathrm{ct}}\right)$; where, $\mathrm{p}=$ disappearance $(\%)$ of DM from the bags at the time $t, a=$ proportion of immediately soluble faction of DM $(\mathrm{g} / \mathrm{kg}), \mathrm{b}$ $=$ potentially but not immediately degradable fraction $(\mathrm{g} / \mathrm{kg})$, $\mathrm{c}=$ fractional rate of soluble degradation $(\% / \mathrm{h})$ of $\mathrm{b}$ and $\mathrm{t}$ is the incubation time (h). Solubility of DM were determined similarly by washing of $0 \mathrm{~h}$ bags.

The effective degradability (ED) of DM were calculated using the equation shown below: $E D=a+b[c /(c+k)]$; where $\mathrm{k}$ assuming the rate of particulate outflow from the rumen, $\mathrm{k}$, is $0.05 \mathrm{~h}^{-1}$ by equation of Ørskov and McDonald (1979).

\section{Statistical analysis}

All data were statistically analyzed according to a completely randomized design using the analysis of variance procedure of SAS (1998). Data were analyzed using the model $\mathrm{Y}_{\mathrm{ij}}=\mu+\mathrm{T}_{\mathrm{i}}+\varepsilon_{\mathrm{ij}}$ where $\mathrm{Y}_{\mathrm{ij}}$ is the observation, $\mu$, the overall mean; $T_{i}$, effect of treatment ( $i=1$ to 3 ); and
Table 1. Yeast and LAB populations in fermented milk

\begin{tabular}{lccc}
\hline \multirow{2}{*}{$\begin{array}{l}\text { Time of incubation } \\
\text { (h) }\end{array}$} & \multicolumn{2}{c}{ Log cell $/ \mathrm{mL}$} & \multirow{2}{*}{$\mathrm{pH}$} \\
\cline { 2 - 3 } & Yeast & LAB & \\
\hline 0 & $3.48^{\mathrm{f}}$ & $3.74^{\mathrm{e}}$ & $7.01^{\mathrm{a}}$ \\
4 & $3.80^{\mathrm{e}}$ & $4.37^{\mathrm{d}}$ & $6.30^{\mathrm{b}}$ \\
8 & $4.00^{\mathrm{d}}$ & $4.00^{\mathrm{c}}$ & $5.20^{\mathrm{c}}$ \\
24 & $4.85^{\mathrm{b}}$ & $6.77^{\mathrm{b}}$ & $4.51^{\mathrm{d}}$ \\
48 & $6.87^{\mathrm{b}}$ & $9.67^{\mathrm{a}}$ & $3.70^{\mathrm{e}}$ \\
72 & $6.90^{\mathrm{a}}$ & $9.67^{\mathrm{a}}$ & $3.40^{\mathrm{f}}$ \\
96 & $6.91^{\mathrm{a}}$ & $9.66^{\mathrm{a}}$ & $3.30^{\mathrm{f}}$ \\
SEM & 0.006 & 0.042 & 0.080 \\
p-value & 0.0001 & 0.0001 & 0.0001 \\
\hline
\end{tabular}

LAB, lactic acid bacteria; SEM, sum square error of the mean.

${ }^{\mathrm{a}-\mathrm{f}}$ Means in the same row with different superscripts differ $(\mathrm{p}<0.05)$.

$\varepsilon_{\mathrm{ij}}$, the residual effect. Differences between treatment means were determined by Duncan's New Multiple Range Test (Steel and Torrie, 1980). Supplement level's trends were analyzed by using orthogonal polynomials. Differences between means with $\mathrm{p}<0.05$ were accepted as representing statistically significant differences.

\section{RESULTS AND DISCUSSION}

\section{Kinetics growth of yeast and lactic acid bacteriaco- culture in fermented milk}

Kinetics growth of yeast and LAB co-culture in fermented milk are shown in Table 1 and Figure 1. The population of yeast was the highest $(p<0.01) \quad(6.90 \mathrm{log}$ cell $/ \mathrm{mL}$ ) started from 72 h-post cultivation while LAB started from 48 h-post cultivation ( $9.67 \log$ cell $/ \mathrm{mL})$. Under current study, optimal cultivation time was in agreement with Polyorachet al. (2013) who reported that yeast fermented liquid at $66 \mathrm{~h}$ post-cultivation was $3 \times 10^{11}$ cell $/ \mathrm{mL}$.

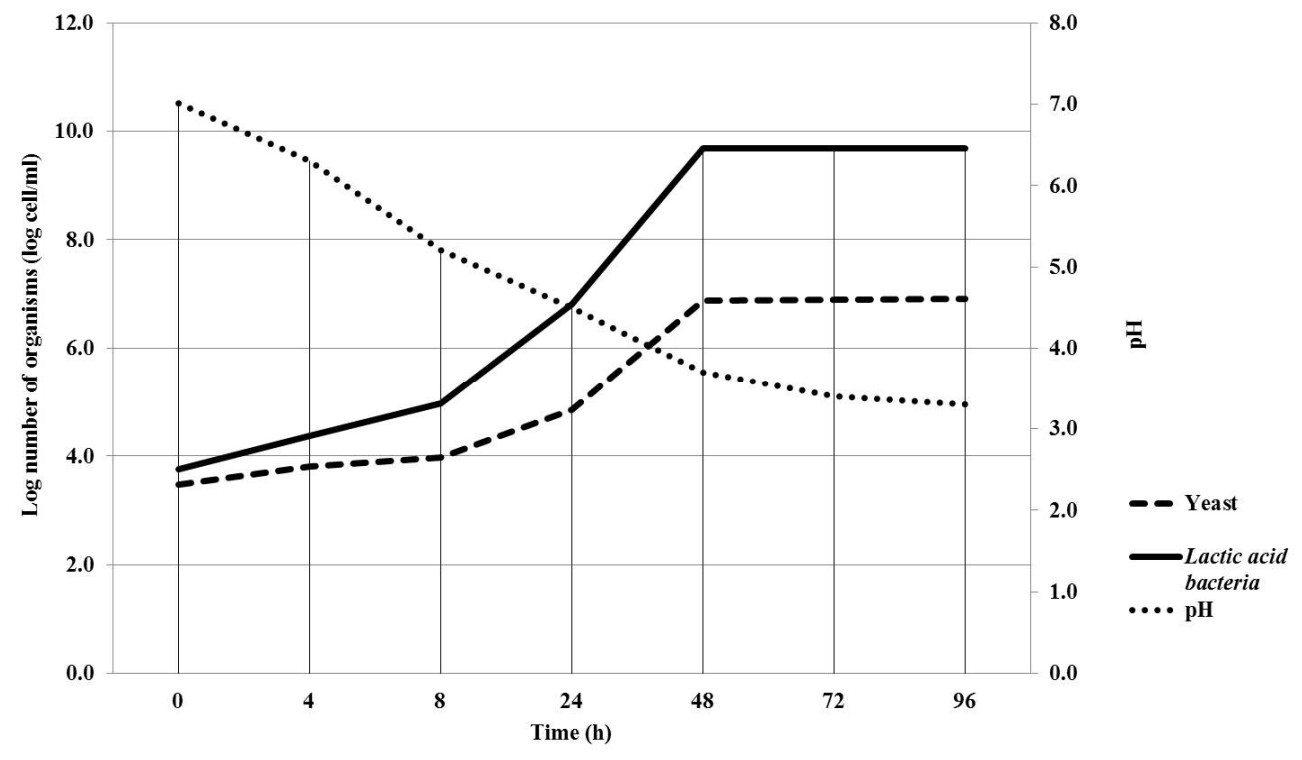

Figure 1. Yeast and LAB populations and $\mathrm{pH}$ changes in fermented milk at different cultivation times. 
In addition, Narvhus and Gadaga (2003) also reported that the fermentation of natural fermented milk usually takes 2 to 3 days and if the product is immediately consumed, or kept under refrigeration, then any effect of interaction between yeasts and LAB in the product has to be evident within this short fermentation period. The yeast counts recorded in this study were in similar range to those reported by Mathara et al. (2008) who found yeasts counts of $<1.0$ to $7.4 \log 10 \mathrm{cfu} / \mathrm{mL}$. The presence of yeast in traditionally fermented milk products, in varying numbers, has been reported by Kebedeet al. (2007). The frequent concurrence of LAB and yeasts has led to the suggestion that there could be interactions that may an influence the product characteristics and quality (Narvhus and Gadaga, 2003).

The fermented milk $\mathrm{pH}$ was the highest $(\mathrm{p}<0.01)$ at $0 \mathrm{~h}$ of cultivation $(\mathrm{pH} 7.01)$ and the lowest $(\mathrm{p}<0.01)$ was at $96 \mathrm{~h}$ post-cultivation $(\mathrm{pH}$ 3.4). The decreasing of ruminal $\mathrm{pH}$ might be due to the milk fermentation process where LAB ferments the lactose in the milk to lactic acid. Wszoleket al. (2001) reported that fermented milk products utilize a wide variety of microorganisms to produce a wide variety of products in addition to lactic acid including ethanol, free fatty acids, and acetaldehyde. When yeasts grow with LAB in milk, they need either to be able to obtain sufficient energy-giving substrates from the milk components or to be able to avail themselves of metabolites from LAB. $S$. cerevisiae has been associated with the production of alcohols and other aroma compounds, stimulation of LAB, improvement of nutritional value, and inhibition of undesirable microorganisms (Jespersen, 2003). However, the yeasts present in this product need to be investigated further to establish their exact role in the fermentation process, including their interaction with $\mathrm{LAB}$ and their metabolic properties.

\section{Chemical composition of feeds}

The chemical compositions of concentrates, SBMFM and soybean meal (SBM) are presented in Table 2. Concentrate diets contained DM, OM, CP, EE, NDF, and $\mathrm{ADF}$ at $89.3 \%, 95.9 \% \mathrm{DM}, 14.2 \% \mathrm{DM}, 3.3 \% \mathrm{DM}, 16.6 \%$ DM and $12.4 \%$ DM, respectively. Moreover, SBMFM diets contained DM, OM, CP, EE, NDF, and ADF at 92.0\%, 94.0\% DM, 58.9\% DM, 6.2\% DM, 11.3\% DM, and 6.5\% $\mathrm{DM}$, respectively. The $\mathrm{CP}$ and $\mathrm{EE}$ of SBMFM in the present study were increased compared to SBM. These results were consistent with the findings reported by Polyorach et al. (2014b) who showed that when soybean meal was fermented with milk by yeast and LAB the nutritive values of soybean meal, especially $\mathrm{CP}$ and EE, were significantly improved. The increase of CP and EE of SBMFM could be due to the effect of microorganisms (yeast and LAB) which could utilize milk and soybean meal and also products from
Table 2. Ingredients and chemical composition of concentrate used in this experiment

\begin{tabular}{lccc}
\hline Item & Concentrate & SBMFM & SBM \\
\hline Ingredient (\% of DM) & & & \\
Cassava chip & 69.1 & - & - \\
Rice bran & 10 & - & - \\
Soy bean meal & 5 & - & - \\
Cotton seed & 10 & - & - \\
Urea & 2.4 & - & - \\
Molasses & 2 & - & - \\
Salt & 0.5 & - & - \\
Sulfur & 0.5 & - & - \\
Premixed & 0.5 & - & - \\
Chemical composition $(\%$ of DM) & & \\
DM & 89.3 & 92.0 & 97.4 \\
OM & 95.9 & 94.0 & 93.3 \\
CP & 14.2 & 58.9 & 46.8 \\
EE & 3.3 & 6.2 & 3.2 \\
NDF & 16.6 & 11.3 & 12.8 \\
ADF & 12.4 & 6.5 & 10.2 \\
\hline
\end{tabular}

SBMFM, soybean meal fermented milk; SBM, soybean meal; DM, dry matter; OM, organic matter; $\mathrm{CP}$, crude protein; $\mathrm{EE}$, ether extract; NDF, neutral detergent fiber; $\mathrm{ADF}$, acid detergent fiber.

fermented milk. Based on the previous works of Wanapat et al. (2011) and Polyorach et al. (2012, 2013, 2014a), it was reported that yeast could be prepared to increase CP content of cassava chip up to $30 \%$ or $47 \%$ of DM. Nasseri et al. (2011) and Yamada and Sgarbieri (2005) found that yeast $(S$. cerevisiae) is rich in protein, soluble fiber, some minerals, and predominantly saturated fatty acids. Therefore, the product of SBMFM could be used as a source of protein for ruminant feeding which could improve productivity and this could increase the economic gains for both dairy farming and fattening cattle.

\section{Ruminal environment}

Ruminal $\mathrm{pH}$ and temperature in various hours post feeding are shown in Table 3. The average ruminal $\mathrm{pH}$ and temperature were $6.5^{\circ} \mathrm{C}$ and $39.1^{\circ} \mathrm{C}$, respectively. Supplementation of SBMFM in the present study changed

Table 3. Ruminal $\mathrm{pH}$ and temperature of crossbred beef steers during the nylon bag study in various incubation time

\begin{tabular}{lcl}
\hline Hour post incubation time & Temperature $\left({ }^{\circ} \mathrm{C}\right)$ & $\mathrm{pH}$ \\
\hline 0 & 38.8 & 7.1 \\
2 & 38.9 & 6.9 \\
4 & 39.4 & 6.9 \\
6 & 39.3 & 6.8 \\
12 & 39.4 & 6.9 \\
24 & 39.4 & 6.8 \\
48 & 38.9 & 7.0 \\
72 & 38.9 & 6.9 \\
Means & 39.1 & 6.9 \\
\hline
\end{tabular}




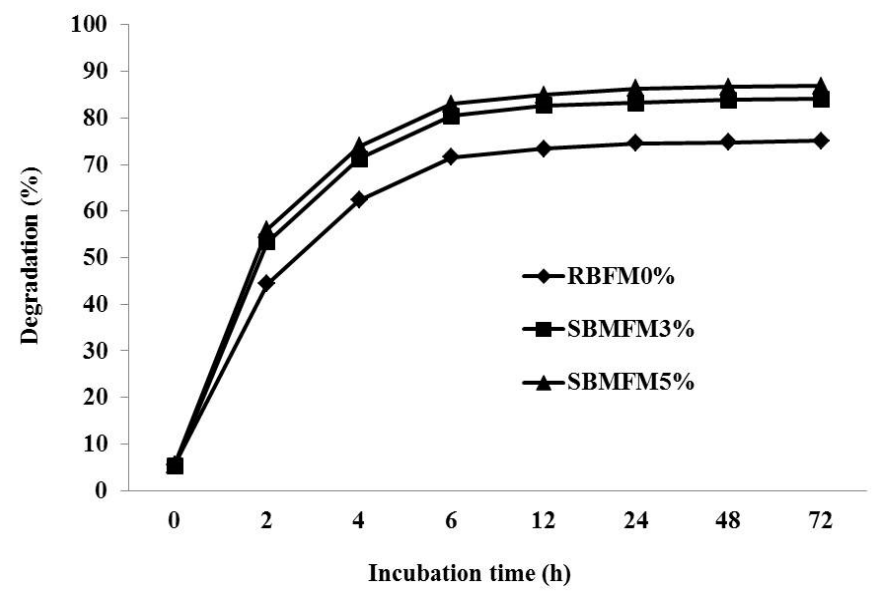

Figure 2. In sacco degradability characteristics of the feedstuffs.

neither ruminal $\mathrm{pH}$ nor temperature. Chanjula et al. (2003) reported that ruminal $\mathrm{pH}$ and temperature ranged from 6 to 7 and $39^{\circ} \mathrm{C}$, respectively, and were considered to be an optimal range for the microbial activity in the rumen. Change of ruminal $\mathrm{pH}$ after one hour post feeding could be due to greater amounts of starch in concentrate diets which may yield greater lactic acid concentration (Kang et al., 2014; 2015) thus a lowered ruminal $\mathrm{pH}$.

\section{Ruminal dry matter disappearance and characteristics}

The effects of SBMFM supplementation on degradability characteristics are presented in Figure 2 and Table 4. The finding of current study revealed that the soluble fractions at time zero (a) was linearly $(p<0.05)$ increased with increased supplemental levels and the highest was at $5 \%$ of total concentrate substrate supplemented group. Moreover, the potential degradability $(\mathrm{a}+\mathrm{b})$ and effective degradability of dry matter (EDDM) were quadratically $(p<0.05)$ increased when increasing supplemental levels while the insoluble degradability fractions (b) and the rate of degradation (c) presented did not affect by treatments. The reason could be the effect of SBMFM as a high quality protein source developed from soybean meal by fermentation with milk and microbes (yeast and LAB) (Polyorach et al., 2014b) on microbial activity and the digestion of $\mathrm{N}$ in the rumen. Traore et al. (2010) reported an improvement in feed digestibility and microbial activity when degradable protein was added in the rumen. Faster and more completed digestion of the feed by microbes apparently reduces the fill of the feed in the rumen. Khy et al. (2012) reported that supplementation of protein source (Leucaena leucocephala) at $450 \mathrm{~g} / \mathrm{h} / \mathrm{d}$ could improve voluntary intake, digestibility, and rumen fermentation parameters in swamp buffaloes.

Moreover, SBMFM also contained yeast and LAB which improved feed utilization by promoting ruminal microbes. Yeast can promote the growth of cellulolytic bacteria and lactate-utilizing bacteria. Yeast also stimulates bacterial growth through removal of oxygen that occurs in ruminal fluid and in that way prevents oxygen toxicity to the ruminal anaerobes (Chaucheyras-Durand et al., 2008; Doto and Liu, 2011). Jouany (2006) reported that yeast culture could consume oxygen in rumen fluid that enters the rumen by coating with feed particles. Yeast culture, in addition, could provide some of the important nutrients and co-factors (vitamins B) to ruminal microflora. Mosoni et al. (2007) found that proportions of 16S ribosomal RNA of the three main cellulolytic bacterial species (F. succinogenes, $R$. albus, and $R$. flavefaciens) increased in the rumen of sheep fed with yeast. Additional of $S$. cerevisiae leads to increase

Table 4. Effect of soybean meal fermented milk (SBMFM) supplementation on dry matter disappearances

\begin{tabular}{|c|c|c|c|c|c|c|}
\hline \multirow{2}{*}{$\begin{array}{l}\text { Degradability characteristics }{ }^{1} \\
(\%)\end{array}$} & \multicolumn{3}{|c|}{ Levels of supplement ( $\%$ of total concentrate substrate) } & \multirow{2}{*}{ SEM } & \multicolumn{2}{|c|}{ Orthogonal polynomial } \\
\hline & 0 & 3 & 5 & & Linear & Quadratic \\
\hline $\mathrm{a}$ & $6.18^{\mathrm{a}}$ & $3.75^{\mathrm{b}}$ & $6.87^{\mathrm{b}}$ & 2.15 & $*$ & $\mathrm{~ns}$ \\
\hline $\mathrm{b}$ & 80.82 & 79.9 & 79.51 & 1.93 & ns & $\mathrm{ns}$ \\
\hline $\mathrm{c}$ & 0.488 & 0.482 & 0.479 & 0.01 & ns & ns \\
\hline$a+b$ & $74.65^{\mathrm{a}}$ & $83.65^{\mathrm{b}}$ & $86.38^{\mathrm{b}}$ & 0.70 & $* *$ & * \\
\hline EDDM & $71.71^{\mathrm{a}}$ & $80.32^{\mathrm{b}}$ & $82.92^{\mathrm{b}}$ & 0.66 & $* *$ & $*$ \\
\hline
\end{tabular}

SBMFM, soybean meal fermented milk; SEM, standard error of the mean; ns, non-significant different; EDDM, effective degradability of dry matter.

${ }^{1} \mathrm{a}=$ soluble at time zero (\%); $\mathrm{b}=$ the fraction for DM which will be degraded when given sufficient time for digestion in the rumen (\%); $\mathrm{c}=$ rate constant for disappearance of fraction $b\left(h^{-1}\right) ; a+b=$ potential degradability. Degradability in the rumen (assuming rate of passage of $0.05 / h^{-1}$ ).

a,b,c Value on the same row with different superscripts differ $(\mathrm{p}<0.05),{ }^{*} \mathrm{p}<0.05,{ }^{* *} \mathrm{p}<0.01$. 
germination of zoospores from a rumen fungal strain of Neocallimastix frontalis as shown in in vitro study (Chaucheyras-Durand et al., 2008). Wanapat et al. (2013) and Polyorach et al. $(2013,2014 \mathrm{a})$ used yeast to improve the nutritional value of cassava chips (YEFECAP) by increasing ruminal microorganisms and thereby improving nutrient digestibility of ruminants.

In addition, LAB could interact with rumen microorganisms in such a way that their activity is enhanced feed utilization, in a recent study (Khuntia and Chaudhary, 2002), dietary addition of a mixed culture of LAB increased DM intake, weight gain, and DM digestibility in calves. Salawu et al. (2001) found that application of Lactobacillus plantarum to pea-wheat silage increased the rate of nitrogen and NDF degradation in the rumen. Malik and Sharma (1998) inoculated rumen fluid with various microorganisms in the presence of wheat straw and concentrates, and found that Lactobacillus acidophilus improved DM and OM digestibility in vitro, compared with an untreated control.

\section{CONCLUSION}

Based on this study, it could be concluded that milk fermented to the optimal time of 72 h-post cultivation resulted in the highest yeast and $\mathrm{LAB}$ populations. Moreover, supplementation of SBMFM could improve degradability in the rumen. This study suggested that SBMFM could be used as a high quality protein source with the supplemental level up to $5 \%$ of total concentrate substrate. However, further research should be investigated in in vivo trial on ruminal performance and animal production.

\section{CONFLICT OF INTEREST}

We certify that there is no conflict of interest with any financial organization regarding the material discussed in the manuscript.

\section{ACKNOWLEDGMENTS}

The authors would like to express their most sincere thanks to all who have assisted and supported the research in this study, particularly Department of Animal Science, Faculty of Natural Resources, Rajamangala University of Technology-Isan, Phang Khon, Sakon Nakhon, Thailand for their kind facilitation in the use of the equipment, laboratory and analysis. This work was also supported by Increase Production Efficiency and Meat Quality of Native Beef and Buffalo Research Group, Khon Kaen University.

\section{REFERENCES}

AOAC. 1990. Official Methods of Analyses, 15th edn. Association of Official Analytical Chemists, Arlington, VA, USA.

Boonnop, K., M. Wanapat, and C. Navanukraw. 2010. Replacement of soybean meal by yeast fermented-cassava chip protein (YEFECAP) in concentrate diets fed on rumen fermentation, microbial population and nutrient digestibilities in ruminants. J. Anim. Vet. Adv. 9:1727-1734.

Boonnop, K., M. Wanapat, N. Nontaso, and S. Wanapat. 2009. Enriching nutritive value of cassava root by yeast fermentation. Sci. Agric. 66:629-633.

Canibe, N. and B. B. Jensen. 2012. Fermented liquid feedmicrobial and nutritional aspects and impact on enteric diseases in pigs. Anim. Feed Sci. Technol. 173:17-40.

Chanjula, P., M. Wanapat, C. Wachirapakorn, S. Uriyapongson, and P. Rowlinson. 2003. Ruminal degradability of tropical feeds and their potential use in ruminant diets. Asian Australas. J. Anim. Sci. 16:211-216.

Chaucheyras-Durand, F., N. D. Walker, and A. Bach. 2008. Effects of active dry yeasts on the rumen microbial ecosystem: Past, present and future. Anim. Feed Sci. Technol. 145:5-26.

Chen, X. B. 1996. An Excel Application Program for Processing Feed Degradability Data. User Manual, Rowett Research Insitute, Bucksburn, Aberdeen, UK.

Doto, S. P. and J. X. Liu. 2011. Effects of direct-fed microbials and their combinations with yeast culture on in vitro rumen fermentation characteristics. J. Anim. Feed Sci. 2:259-271.

Goering, H. K. and P. J. Van Soest. 1970. Forage Fiber Analysis (apparatus, reagent, procedures and some application). US Agricultural Research Service, Washington, DC, USA.

Jespersen, L. 2003. Occurrence and taxonomic characteristics of strains of Saccharomyces cerevisiae predominant in African indigenous fermented foods and beverages. FEMS Yeast Res. 3:191-200.

Jouany, J. P. 2006. Optimizing rumen functions in the close-up transition period and early lactation to drive dry matter intake and energy balance in cows. Anim. Reprod. Sci. 96:250-264.

Kang, S., M. Wanapat, and A. Cherdthong. 2014. Effect of banana flower powder supplementation as a rumen buffer on rumen fermentation efficiency and nutrient digestibility in dairy steers fed on high concentrate diet. Anim. Feed Sci. Technol. 196:3241.

Kang, S., M. Wanapat, A. Cherdthong, and K. Phesatcha. 2015. Comparison of banana flower powder and sodium bicarbonate supplementation on rumen fermentation and milk production in dairy cows. Anim. Prod. Sci., 2015 http://dx.doi.org/ 10.1071/AN15055

Kebede, A., B. C. Viljoen, T. H. Gadaga, J. A. Narvhus, and A. Lourens-Hattingh. 2007. The effect of container type on the growth of yeast and lactic acid bacteria during production of sethemi, South African spontaneously fermented milk. Food Res. Int. 40:33-38.

Khuntia, A. and L. C. Chaudhary. 2002. Performance of male crossbred calves as influenced by substitution of grain by wheat bran and the addition of lactic acid bacteria to diet. Asian Australas. J. Anim. Sci. 15:188-194.

Khy, Y., M. Wanapat, T. Haitook, and A. Cherdthong. 2012. Effect 
of Leucaena Leucocephala pellet (LLP) supplementation on rumen fermentation efficiency and digestibility of nutrient in swamp buffalo. J. Anim. Plant Sci. 22:564-569.

Malik, R. and D. D. Sharma. 1998. In vitro evaluation of different probiotics as feed supplement. Indian J. Dairy Sci. 51:357-362.

Mathara, J. M., U. Schillinger, C. Guigas, C. Franz, P. M. Kutima, S. K. Mbugua, H. K. Shin, and W. H. Holzapfel. 2008. Functional characteristics of Lactobacillus spp. from traditional Maasai fermented milk products in Kenya. Int. J. Food Microbiol. 126:57-64.

Mosoni, P., F. Chaucheyras-Durand, C. Béra-Maillet, and E. Forano. 2007. Quantification by real-time PCR of cellulolytic bacteria in the rumen of sheep after supplementation of a forage diet with readily fermentable carbohydrates: Effect of a yeast additive. J. Appl. Microbiol. 103:2676-2685.

Narvhus, J. A. and T. H. Gadaga. 2003. The role of interaction between yeasts and lactic acid bacteria in African fermented milks: A review. Int. J. Food Microbiol. 86:51-60.

Nasseri, A. T., S. Rasoul-Amini, M. H. Morowvat, and Y. Ghasemi. 2011. Single cell protein: Production and process. Am. J. Food Technol. 6:103-116.

Oboh, G. and A. A. Akindahinsi. 2003. Biochemical changes in cassava products (flour and gari) subjected to Sacchromy cescerevisiae solid media fermentation. Food Chem. 82:599602.

Ørskov, E. R. and I. McDonald. 1979. The estimation of protein degradability in the rumen from incubation measurements weighted according to rate of passage. J. Agric. Sci. 92:499503.

Polyorach, P., M. Wanapat, and S. Wanapat. 2012. Increasing protein content of cassava (Manihot esculenta, Crantz) using yeast in fermentation. Khon Kaen Agric. J.40:178-182.

Polyorach, S., M. Wanapat, and A. Cherdthong. 2014a. Influence of yeast fermented cassava chip protein (YEFECAP) and roughage to concentrate ratio on ruminal fermentation and microorganisms using in vitro gas production technique. Asian Australas. J. Anim. Sci. 27:36-45.

Polyorach, S., M. Wanapat, and S. Wanapat. 2013. Enrichment of protein content in cassava (Manihot esculenta Crantz) by supplementing with yeast for use as animal feed. Emir. J. Food Agric. 25:142-149.
Polyorach, S., O. Poungchompu, M. Wanapat, U. Supachat, O. Saihatwong, and G. Chaiyayong. 2014b. The improving of soybean meal nutritive value by using yeast and lactic acid bacteria in raw milk. Khon Kaen Agric. J. 42:358-362.

Pond, W. G., D. C. Church, and K. R. Pond. 2005. Basic Animal Nutrition and Feeding. 5th edn. John Wiley \& Sons, Inc., Danvers, MA, USA.

Salawu, M. B., A. T. Adesogan, C. N. Weston, and S. P. Williams. 2001. Dry matter yield and nutritive value of pea/wheat bicrops differing in maturity at harvest, pea to wheat ratio and pea variety. Anim. Feed Sci. Technol. 94:77-87.

SAS. 1998. User's Guide: Statistic, Version 6. 12th edn. SAS Inst. Inc., Cary, NC, USA.

Steel, R. G. D. and J. H. Torrie. 1980. Principles and Procedures of Statistics. (2nd edn). McGraw Hill Book Company, Inc., New York, USA.

Sugiharto, S., C. Lauridsen, and B. B. Jensen. 2015. Gastrointestinal ecosystem and immunological responses in $E$. coli challenged pigs after weaning fed liquid diets containing whey permeate fermented with different lactic acid bacteria. Anim. Feed Sci. Technol. 207:278-282.

Traore, I. A., G. C. Akouedegni, S. Babatounde, and R. H. Bosma. 2010. Effects of protein supplementation during the dry season on the feed intake and performances of Borgou cows in the sudanian zone of Benin. Adv. Anim. Biosci. 1:449-450.

Wanapat, M. and P. Rowlinson. 2007. Nutrition and feeding of swamp buffalo: Feed resources and rumen approach. Ital. J. Anim. Sci. 6:67-73.

Wanapat, M., S. Kang, and S. Polyorach. 2013. Development of feeding systems and strategies of supplementation to enhance rumen fermentation and ruminant production in the tropics. J. Anim. Sci. Biotechnol. 4:32.

Wanapat, M., S. Polyorach, V. Chanthakhoun, and N. Sornsongnern. 2011. Yeast-fermented cassava chip protein (YEFECAP) concentrate for lactating dairy cows fed on urealime treated rice straw. Livest. Sci. 139:258-263.

Wszolek, M., A. Y. Tamime, D. D. Muir, and M. N. I. Barclay. 2001. Properties of kefir made in Scotland and Poland using bovine, caprine, and ovine milk with different starter cultures. LWT - Food Sci. Technol. 34:251-261.

Yamada, E. A. and V. C. Sgarbieri. 2005. Yeast (Saccha-romyces cerevisiae) protein concentrate: Preparation, chemical composition, and nutritional and functional properties. J. Agric. Food Chem. 53:3931-3936. 